\title{
THE IMPACT OF SOCIAL MEDIA USAGE AND SMARTPHONE ADDICTION ON YOUNGS'/ADOLESCENTS' CAREER FUTURES: A STUDY AT HIGH SCHOOLS ${ }^{1}$
}

Fikret SÖZBILİR ${ }^{2}$
Received Date (Başvuru Tarihi): 20/05/2018

Accepted Date (Kabul Tarihi): 13/07/2018

Published Date (Yayın Tarihi): 02/09/2018

\begin{abstract}
This study aims to determine the impact of social media usage and smartphone addiction of young people, who will be future employees of organizations, on their career future perceptions. In addition, it is aimed to provide recommendations, based on results regarding positive or negative effect of social media and smartphone usage on the formation of the perception of career future. In this empirical study, the data on perceptions concerning social media usage, smartphone addiction, career adaptability, and career futures were gathered by means of a questionnaire from 6259 participating students in Artvin in Turkey. Data were subjected to analysis with SPSS 24.0 software and presented in tables. The findings showed that social media usage has a significant and positive impact on career adaptability and career futures. Also, smartphone addiction has a significant and positive impact on career futures on the other hand it has a negative and significant impact on career adaptability.
\end{abstract}

Keywords: Social media usage, Smartphone addiction, Career futures.

JEL Codes: E24, J24, O15.

\section{SOSYAL MEDYA KULLANIMININ VE AKILLI TELEFON BAĞIMLILIĞIININ GENÇLERIN/ERGENLERIN KARIYER GELECEĞIINE ETKİSİ: LİSELERDE BİR ARASTIRMA}

ÖZ

Bu çalışmanın amacı gelecekte organizasyonların insan kaynăğ olacak gençlerin sosyal medya kullanımının ve akıllı telefon bağımlıllğının onların kariyer geleceği algısı üzerindeki etkisini araștırmaktadır. Ayrıca, sosyal medya kullanımının ve akıllı telefon bağımlılı̆̆ıın onların kariyer geleceği algısının biçimlenmesinde etkisinin olup olmadı̆̆ına dair sonuçlar üzerinden önerilerde bulunmak da amaçlanmıştır. Bu alan çalışmasında anket yoluyla Artvin ilindeki 6259 lise öğrencisinden sosyal medya kullanımı, akillı telefon bağımlıllğı, kariyer uyumluluğu ve kariyer geleceği algılarına ilişkin veriler toplanmıştır. Elde edilen veriler SPSS 24.0 programı ile analiz edilmis ve tablolar halinde sunulmuştur. Bulgular, sosyal medya kullanımının kariyer uyumluluğu ve kariyer geleceği üzerinde olumlu ve anlaml bir etkisinin olduğunu göstermiştir. Aynı zamanda, akıllı telefon bağımlıllğının kariyer geleceğinin üzerinde olumlu ve anlamlı bir etkisinin olduğu, diğer taraftan kariyer uyumluluğu üzerinde olumsuz ve anlamlı bir etkisinin olduğu görülmüştür.

Anahtar Sözcükler: Sosyal medya kullanımı, Akıllı telefon bağımlılı̆̆ı, Kariyer geleceği.

JEL Kodları: E24, J24, O15.

\footnotetext{
${ }^{1}$ This research has been supported by Artvin Coruh University Scientific Research Projects Coordination Department. Project number: 2016.S50.02.12.

${ }^{2}$ Asst. Prof. Dr., Artvin Coruh University, fsozbilir08@ hotmail.com,

http://orcid.org.0000-0003-2665-1795
} 


\section{INTRODUCTION}

The internet one of the most important invention of the century, has led to significant changes in every aspect of human life. It has facilitated life in many areas, the internet is also seen easily overused/abused, moreover addictive (Greenfield, 1999). 21'st-century human resources are changing. They are more digital, more global and social media focused (Walsh and Volini, 2017). Most of the adolescent internet users interest in the web games, socializing and sharing their ideas through social media or blogs. Some of them cannot control themselves and spend much time unaware (Cash et al., 2012). This leads to internet and social media addiction in adolescents. Excessive social media usage and internet addiction cause falling productivity at work or failure in school (Young, 1998). Adolescents, who failed in their education or vocational training, may have problem with career adaptation and career future. They are seen as a group with no motivation on job search and career future. Whereas individuals in the 15-19 age range will create added value if they use social media effectively, and if they are well-trained and participate in production by working in a career-focused way (Dama, 2017). Super (1980: 282, 289) defined the career as "the combination and sequence of roles played by a person during the course of a lifetime" and these roles include student in the exploration stage. The conditions are changing rapidly due to the character of the global economy in recent years, an individual should have additional coping skills and resources to improve his or her career adaptability and career in future (Rottinghaus et al., 2017). Career adaptability is defined as the idea of the individual's own "capacity to cope with and capitalize on change in the future, level of comfort with new work responsibilities, and ability to recover when unforeseen events alter career plans" (Rottinghaus et al., 2005: 11). According to Rottinghaus et al. (2005: 4) career future is an individual's hope, effort and expectation on his or her career in the future and following through to achieve his/her goals. The current study strives to move theory forward to career adaptability and career future by examining the impact of social media usage and smartphone addiction on career adaptability and career future. Also, the study takes place in Turkey and as a non-Western context it allows us to expand our understanding of the global reach of these important theories.

Previous researches emphasized the importance of positive personality traits, selfmanagement skills about coping with problems in vocational and working life and other factors affecting career. Such as, career indecision and career certainty (Fernandes and Bance, 2015), optimism and pessimism (Creed et al., 2002: 42), self-esteem, career expectations, career goals, career planning and career exploration (Patton et al, 2004), cognitive skills (Hall and Farkas, 
2011), socioeconomic status and social class (Eshelman and Rottinghaus, 2015). However, there is no study on the impact of social media usage and smartphone addiction on career adaptability and career future. Consequently, this study addresses the research gap in the careers literature by examining the impact of social media usage and smartphone addiction on career adaptability and career future.

\section{THEORETICAL BACKGROUND}

\subsection{Social Media Usage}

Social media has fast become a tool that brings millions of members together in the virtual environment by providing them with enormous power, opportunities, and competence (Kettunen et al., 2015). Today, as digital generation, over $90 \%$ of adolescents use the social media to share information, photographs, and watch movies, communicate and socialize with one another (Kettunen et al., 2015; Moreno et al. 2016; Brunborg et al., 2017). Kettunen et al. (2015: 43) defined social media as "a process in which individuals and groups develop common understandings and meanings with contents, communities and Web 2.0 technology". Last decade, emerging social media sites has accelerated to build and exploit connections for career management (Benson et al., 2014). The most popular social media sites such as Facebook (Salehan and Negahban, 2013), Twitter, LinkedIn, Youtube and Instagram are frequently accessed and have become valuable tools for job-hunters. Especially, LinkedIn is the most known social media site that can help job candidates and their career (Anders, 2012). There are many specific areas of career. Author examined effect of the social media usage and smart phone addiction on career adaptability and career future in this study.

\subsection{Smartphone Addiction}

Smartphone addiction is defined as "the overuse of smartphones to the extent that it disturbs the users' daily lives" (Demirci et al., 2014:227). Smart phone addiction is characterized by disturbance of adaptive functions, virtual life orientation, withdrawal, and tolerance (Kim et al., 2014).

Disturbance of adaptive functions includes negligence of school activities such as having hard time to do planned studies and concentrating impairment while doing homework or working. Also it includes, family or friends' complaining about one's excessive smartphone use (Kim et al., 2014), and these disturbances leads to a decrease in the level of success. Virtual Life Orientation is described in this study as keeping social life dramatically dependent on smartphone with internet instead of family or friends. Most of the adolescent smartphone users 
have more pleasure while using smartphone than spending time with their families or friends. When they cannot use their smartphone they feel as if they lost their whole world. Withdrawal refers to feeling pain if not allowed to use smartphone also, when one (adolescent) without a smartphone, he or she will be nervous and anxious (Kim et al., 2014). The last factor, tolerance is defined as "always trying to control one's smartphone use but always failing to do so" (Kwon et al., 2013: 7).

\subsection{Career Adaptability}

Career adaptability is defined by Savickas and Porfeli (2012: 662) as "a psychosocial construct that denotes an individual's resources for coping with current and anticipated tasks, transitions, traumas in their occupational roles that, to some degree large or small, alter their social integration". Adaptability also means the capability of adolescents to fit the resulting situation in developing their careers (Savickas, 1997). Career adaptability resources, for short the 4Cs, such as concern, control, curiosity, and confidence are known as four adapt-ability syndromes and also accepted as self-regulatory. These resources are considered as human capital what the individual's knowledge, competencies, and experiences (Savickas and Porfeli, 2012) or integrated skills of these. Concern helps individuals for forethought and their readiness to what they will face in the future. Control provides individuals to manage the events about their vocational future via self-discipline and effort. Curiosity impels a person to think himself in diverse situations and roles. Confidence supports individuals with self-reliance to pursue their value-goals (Savickas and Porfeli, 2012).

\section{Social media and career adaptability}

A study (Giunchiglia et al., 2018: 182), determined that the social media usage has stronger effect on the progress of students' career than on the quality of their study. On the other hand, The reviewed literature carried out that there is a positive relationship between social media usage and co-careering (Kettunen et al., 2015: 53), cultural structure, kinship, friendship (Küçükali, 2016), employability skills gap (Benson et al., 2014), career advancement (McCabe, 2017). Ebenehi, Rashid, and Bakar (2016: 220) found in their studies, that there is a positive relationship between personal goal orientation, perceived social support, career self-efficacy sources and career adaptability. It is seen that the social media usage has positive impact on the career as well as on the negative effects. Similarly, the social media usage may positively affect career adaptability. Therefore, in this research, following hypotheses were developed to test whether the social media usage has impact on career adaptability. 
H1. Social media usage has a positive impact on career adaptability.

Smartphone addiction and career adaptability

In their study Lee et al. (2016), found that oft-use of social networking site applications (apps) leads to smartphone addiction in adolescents. Many researchers determined that there is a significant and positive relationship among depression (Aljomaa et al., 2016), stress (Chiu, 2014; Samaha and Hawi, 2016), and smartphone addiction. Kim et al. (2015) explored that smartphone addiction has negative effect on physical health by reducing the amount of physical activity. On the other hand Samaha and Hawi (2016) found a significant and negative relationship between academic performance and smartphone addiction. Career adaptation and self-efficacy are close terms to each other. In both, it expresses the individual's ability to struggle with difficulties, his belief that he can overcome obstacles, and his ability to adapt to changing circumstances (Schwarzer \& Jerusalem, 1995; Bandura, 1997; Savickas and Porfeli, 2012). Career adaptation and self-efficacy are close terms to each other. In both, it expresses the individual's ability to struggle with difficulties, his belief that he can overcome obstacles, and his ability to adapt to changing circumstances (Schwarzer \& Jerusalem, 1995; Bandura, 1997; Savickas and Porfeli, 2012). In their study, Hong et al., (2012) concluded that self-esteem and self-efficacy has negative effects on mobile phone addiction. Considering the findings of previous studies that and, this study proposed the following hypotheses:

H2. Smartphone addiction has a negative impact on career adaptability.

H2a. Disturbance of adaptive functions have a negative impact on career adaptability.

H2b. Virtual life orientation has a negative impact on career adaptability.

H2c. Withdrawal has a negative impact on career adaptability.

H2d. Tolerance has a negative impact on career adaptability.

\subsection{Career Future}

Career future is accepted as "individuals' outlook on how their career will turn out" (Rottinghaus et al., 2012: 126). Career future comprises the following sub-dimensions: Career agency, Occupational Awareness, Support, Work-Life Balance, and Negative Career Outlook (Rottinghaus et al., 2017). Career agency is closely connected with career adaptability. According to Rottinghaus et al. (2017) career agency is an individual's perceived capacity of self-reflection and forethought to voluntarily initiate, control, and management career transitions. The Career Agency factor includes a combination of items that reflect control, 
confidence, optimism and self-awareness. Occupational awareness implies information about job market and employment trends. Support is perceived as getting motivational and material support from family and friends in pursuing career goals. Work-Life Balance, expresses the capability of a person to realize and operate his/her responsibilities to others throughout his/her multiple life roles. Negative career outlook denotes negative idea about career decisions and opinions that person will not gain desired career outcomes in the future (Rottinghaus et al., 2017).

\section{Social media usage and career future}

In their research, Roman (2014) and McCabe (2017) determined that the act of using social media provides for individual cost-effective opportunities to enhance their personal skill set and career by building communities of practice, participating in professional development events, and enriching classroom learning. Rutten et al. (2016) conducted a survey on students and explored that using social media are most suitable to encourage students/adolescents to practice their online career skills. Social media usage may ensure job connection, promotion opportunity and helps individuals prepare for their career futures by providing share their skills, insights, and talents (Kononova, 2017). According to Mills (2013), a person can increase his/her potential career opportunities by building a professional profile using social media. Taking into account that the findings of early studies, in this research, researcher supposed following hypotheses:

H3. Social media usage has a positive impact on career future.

H3a. Social media usage has a positive impact on career agency.

H3b. Social media usage has a positive impact on occupational awareness.

H3c. Social media usage has a positive impact on support.

H3d. Social media usage has a positive impact on work-life balance.

H3e. Social media usage has a positive impact on negative career outlook.

Smartphone addiction and career future

In their study on information technology addiction, Vaghefi et al. (2017) explored that overuse of smartphone with regard IT addiction has adverse effects on the productivity and performance of users and increases the job turnover for professionals and academic failure for students. CarerBuilder, online career site in human capital solutions, conducted a survey on 2100 human resources managers from United States and confirmed that "the biggest 
productivity killers in the workplace" are cell phones/texting (Lorenz, 2015), another mean smartphone addiction. It is well known that a non-productive person is not preffered for career, and this is negatively affects career future. Cha and Seo (2018) conducted a survey on 1824 middle school students who used a smartphone in South Korea. They were sampled randomly from strata based on city, age, and sex. The average age of the students was 15.6 years. They explored that there is no significant difference in career plans in future between risk group for smartphone addiction and normal user groups. Moreover 75.9 percent of them had a career plan in futures. In this study, following hypotheses were developed in order to test whether smartphone addiction and its dimensions has an impact on career futures:

H4. Smartphone addiction has a negative impact on career future.

H4a. Disturbance of adaptive functions has a negative impact on career future.

H4b. Virtual Life Orientation has a negative impact on career future.

H4c. Withdrawal has a negative impact on career future.

H4d. Tolerance has a negative impact on career future.

Career adaptability and career future

According to Hartung and Cadaret (2017: 20) career adaptability improves completing duties related with each process to create flexibility and a basis for future career satisfaction and success. Ginevra et al. (2016) surveyed on 774 adolescent in Taiwan and determined that there is a positive and significant relationships between career adaptability and elements supporting career futures such as hope, optimism, and future orientation. An other study (Taber \& Blankemeyer, 2015), explored that career adaptability has impact on proactive career behavior. Consequently, career adaptability and its dimensions (e.g. Concern, Control, Curiosity, and Confidence) may make a contribution to improve the positive emotions and expectance. Thus, current study proposed the following hypotheses:

H5. Career adaptability has a positive impact on career future.

H5a. Concern has a positive impact on career future.

H5b. Control has a positive impact on career future.

H5c. Curiosity has a positive impact on career future.

H5d. Confidence has a positive impact on career future. 


\section{METHOD}

\subsection{Participants and Procedure}

The data were collected by means of an anonymous self-report questionnaire that was distributed to 9540 students in 35 regular, vocational, technical and science high schools in Artvin, Turkey. A total of 6427 students/adolescents participated in the survey (67\%) but the effective sample size was 6259 because 168 respondents were over 18 years old, and they were over the age of adolescence. The data has been analysed by the statistical data analysis package programme named as SPSS 24.0. The data regarding the demographic results of the students were evaluated through frequency and percent values.

As a result, $49.4 \%$ of the participants were male and $50.6 \%$ of participants were female. $52.2 \%$ of the participants are between $15-16$ years old and $3.1 \%$ of the participants are between 13-14 years old. $40.1 \%$ of participant study at Anatolian High School and 1.7\% of participants at Trade Vocational High School. $82.9 \%$ of decision factor of participants at job selection is themselves and $0.5 \%$ is their friends. $41.2 \%$ of participants have Facebook social network. $29.5 \%$ of participants use between 1 and 2 hours in social network and $10.1 \%$ of participants use between 4 and 9 hours in social network. $85.5 \%$ of participants have a smart phone and $14.5 \%$ of them have not. $79.5 \%$ of participants have an internet package on smart phone and $20.5 \%$ of them have not. $71.9 \%$ of participants buy an internet package with their family's money aid and $28.1 \%$ of them buy themselves. $90.9 \%$ of participants have more than 300 friends in social network that is the most used and $46.3 \%$ of them have between 501 and 1000 . $27.8 \%$ of participant study in first class at the high school and $19.4 \%$ of them study in fourth class.

Table 1: Demographic Results of the Participants

\begin{tabular}{|l|r|r|l|r|r|}
\hline $\begin{array}{l}\text { Daily Allowance } \\
(\text { TRY) }\end{array}$ & $\mathrm{N}$ & $\begin{array}{r}\text { Percent } \\
(\%)\end{array}$ & High-School & $\begin{array}{r}\text { Percent } \\
(\%)\end{array}$ \\
\hline 1 & 239 & 3.8 & Anatolian High School & 2512 & 40.1 \\
\hline 2 & 446 & 7.1 & Technical Vocational High School & 481 & 7.7 \\
\hline 3 & 799 & 12.8 & Imam Hatip High School & 1248 & 19.9 \\
\hline 4 & 138 & 2.2 & Health Vocational High School & 420 & 6.7 \\
\hline 5 & 3220 & 51.4 & Girl Vocational High School & 235 & 3.8 \\
\hline $6-9$ & 235 & 3.8 & Trade Vocational High School & 109 & 1.7 \\
\hline 10 & 1035 & 16.5 & Multi-Program High School & 629 & 10.1 \\
\hline $11-13$ & 12 & 0.2 & Science High School & 625 & 10.0 \\
\hline $14-16$ & 135 & 2.2 & & & \\
\hline Total & 6259 & 100.0 & Total & 6259 & 100.0 \\
\hline
\end{tabular}


bmij (2018) 6 (2): 466-487

\begin{tabular}{|c|c|c|c|c|c|}
\hline High School Grades & $\mathrm{N}$ & $\begin{array}{r}\text { Percent } \\
(\%)\end{array}$ & Factor of Job Selection & $\mathrm{N}$ & $\begin{array}{r}\text { Percent } \\
(\%) \\
\end{array}$ \\
\hline 1 & 1736 & 27.8 & Select Myself & 5189 & 82.9 \\
\hline 2 & 1684 & 26.9 & Direction of My Family & 515 & 8.2 \\
\hline 3 & 1623 & 25.9 & Select For Friend in Same Job & 31 & 0.5 \\
\hline 4 & 1216 & 19.4 & For High Income & 354 & 5.7 \\
\hline \multirow[t]{2}{*}{ Total } & 6259 & 100.0 & For Respectful Job & 170 & 2.7 \\
\hline & & & Total & 6259 & 100.0 \\
\hline $\begin{array}{l}\text { Numbers of Friend in } \\
\text { Social Network that the } \\
\text { Most Used }\end{array}$ & $\mathrm{N}$ & $\begin{array}{r}\text { Percent } \\
(\%)\end{array}$ & $\begin{array}{l}\text { Total Time in Social Network } \\
\text { Usage in a Day }\end{array}$ & $\mathrm{N}$ & $\begin{array}{r}\text { Percent } \\
(\%)\end{array}$ \\
\hline There is no friend & 412 & 6.6 & Never & 485 & 7.8 \\
\hline $1-100$ & 710 & 10.3 & $<10$ Minutes & 526 & 8.4 \\
\hline $101-500$ & 2895 & 46.3 & Between 10 and 30 Minutes & 1128 & 18.0 \\
\hline $501-1000$ & 1133 & 18.1 & Between 30 Minutes and 1 Hour & 1215 & 19.4 \\
\hline $1001-2000$ & 612 & 9.8 & Between 1 and 2 Hours & 1283 & 20.5 \\
\hline $2001-3000$ & 156 & 2.5 & Between 2 and 3 Hours & 674 & 10.8 \\
\hline $3001-5000$ & 152 & 2.4 & Between 3 and 4 Hours & 312 & 5.0 \\
\hline 5001 and more & 189 & 3.0 & Between 4 and 9 Hours & 636 & 10.1 \\
\hline Total & 6259 & 100.0 & Total & 6259 & 100.0 \\
\hline Internet in Smartphone & $\mathrm{N}$ & $\begin{array}{r}\text { Percent } \\
(\%)\end{array}$ & Gender & $\mathrm{N}$ & $\begin{array}{r}\text { Percent } \\
(\%) \\
\end{array}$ \\
\hline Have & 4251 & 79.5 & Male & 3092 & 49.4 \\
\hline Not Have & 3008 & 20.5 & Female & 3167 & 50.6 \\
\hline Total & 6259 & 100.0 & Total & 6259 & 100.0 \\
\hline Age Groups & $\mathrm{N}$ & $\begin{array}{r}\text { Percent } \\
(\%)\end{array}$ & How to Buy Internet Package & $\mathrm{N}$ & $\begin{array}{r}\text { Percent } \\
(\%)\end{array}$ \\
\hline $13-14$ & 198 & 3.1 & Buy myself & 1759 & 28.1 \\
\hline $15-16$ & 3265 & 52.2 & My family buy to me & 4500 & 71.9 \\
\hline $17-18$ & 2796 & 44.7 & Total & 6259 & 100.0 \\
\hline Total & 6259 & 100.0 & & & \\
\hline Social Network & $\mathrm{N}$ & $\begin{array}{r}\text { Percent } \\
(\%)\end{array}$ & Own Smartphone & $\mathrm{N}$ & $\begin{array}{r}\text { Percent } \\
(\%)\end{array}$ \\
\hline Facebook & 2581 & 41.2 & Have & 5352 & 85.5 \\
\hline Twitter & 148 & 2.4 & Not Have & 907 & 14.5 \\
\hline Instagram & 2507 & 40.1 & Total & 6259 & 100.0 \\
\hline Youtube & 492 & 7.9 & & & \\
\hline $\begin{array}{l}\text { Linkedin, MySpace, } \\
\text { AskFm, Last Fm }\end{array}$ & 13 & 0.2 & & & \\
\hline Never Use & 518 & 8.3 & & & \\
\hline Total & 6259 & 100.0 & & & \\
\hline
\end{tabular}

\subsection{Measures}

\subsubsection{Social Media Usage}

Social media usage was measured using the "Social Media Usage Scale" (Küçükali, 2016). 15-items measured social media usage frequency. A sample item is "I use social media 
for self-presentation and information-sharing". The Cronbach alpha for this scale in the present study was .78. Responses were made on a 5-point scale ranging from 1 (strongly disagree) to 5 (strongly agree). Social media usage scale were already developed and used successfully in the Turkish context (Küçükali, 2016).

\subsubsection{Smartphone addiction}

Smartphone addiction was measured using the "Smartphone Addiction Proneness Scale-SAPS" (Kim et al., 2014). SAPS consisted of four subdomains: disturbance of adaptive functions (5 items), virtual life orientation ( 2 items), withdrawal (4 items), and tolerance (4 items). The four components of scale were measured using the 15-item scales. Responses were made on a 5-point scale ranging from 1 (strongly disagree) to 5 (strongly agree). The reliability coefficient of overall SAPS was .82. Sample items of these scales are "My school grades dropped due to excessive smartphone use" (disturbance of adaptive functions, Cronbach alpha= .78), "Using a smartphone is more enjoyable than spending time with family or friends." (virtual life orientation, Cronbach alpha= .78), "It would be painful if I am not allowed to use a smartphone." (withdrawal, Cronbach alpha $=.77$ ), and "I try cutting my smartphone usage time, but I fail" (tolerance, Cronbach alpha $=.75$ ).

\subsubsection{Career adaptability}

Career adaptability skill was measured by the use of Career Adapt-Abilities Scale (CAAS) (Savickas and Porfeli, 2012). CAAS consisted of 24-items and four subdomains: concern, control, curiosity, and confidence. Each subdomain has 6 items. The reliability coefficient of CAAS was .90. Responses were made on a 5-point scale ranging from 1 (strongly disagree) to 5 (strongly agree). Sample items of these scales are "Thinking about what my future will be like" (concern, Cronbach alpha= .87), "Keeping upbeat" (control, Cronbach alpha= .87), "Exploring my surroundings" (curiosity, Cronbach alpha $=.88$ ), and "Performing tasks efficiently" (tolerance, Cronbach alpha $=.86$ ). CAAS were used successfully in the Turkish context (Kanten, 2012).

\subsubsection{Career Futures}

Career futures was measured by the use of Career Futures Inventory-Revised (CFI-R) (Rottinghaus et al., 2012). CFI-R consisted of 28-items and five subdomains: career agency (10 items), occupational awareness (5 items), support (3 items), work-life balance (4 items), negative career outlook (4 items). Two items were excluded (1 item from occupational awareness and 1 item from support subdomains) from CFI-R scale, because their reliability 
coefficients were low. The reliability coefficient of overall CFI-R was .88. Responses were made on a 5-point scale ranging from 1 (strongly disagree) to 5 (strongly agree). Sample items of these scales are "I can perform a successful job search" (career agency, Cronbach alpha= .88), "I am good at understanding job market trends" (occupational awareness, Cronbach alpha $=.70$ ), "Others in my life are very supportive of my career" (support, Cronbach alpha= .66) and "I am very strategic when it comes to balancing my work and personal lives" (worklife balance, Cronbach alpha= .70). I lack the energy to pursue my career goals (negative career outlook, Cronbach alpha $=.71)$. The original smartphone addiction and career future revisedinventory (CFI-R) scales were constructed in English and they were not translated into Turkish before. Thus, these scales were translated into Turkish. In-depth interviews were conducted with two Turkish academician working as English lecturer from various universities to ensure an accurate interpretation of the items. Subsequently, the translated scales were back reported in this paper in English by the researcher with the original English version of the scales.

\section{RESULTS}

\subsection{Validity Test of Scales}

The validity of the constructs of interest was tested using factor analysis. Social media usage, smartphone addiction proneness (SAPS), career adapt-abilities (CAAS), and career futures inventory-revised (CFI-R) scales were factor analyzed using orthogonal rotation (varimax). Exploratory factor analysis was performed to examine the factor structures of the all scales and to select the items with high factor loadings. KMO values of all scales indicated that the correlation matrixes were suitable for factor analysis. The significance of a factor loading will depend on the sample size. A sample size of 1000 a loading of 0.162 can be considered significant. Therefore, in very large samples, small loadings can be considered statistically meaningful (Field, 2009: 644). Consequently, the exploratory factor analyses demonstrate that the translated scales performed as expected and yielded satisfactory results. Exploratory factor analysis results are presented in Table 2. 
Table 2: Factor Analysis Results

\begin{tabular}{|c|c|c|c|c|c|c|}
\hline Variables & $\begin{array}{r}\text { Factor } \\
\text { Loadings }\end{array}$ & $\mathrm{KMO}$ & Approx. $\chi^{2}$ & df & $\begin{array}{r}\text { Variance } \\
(\%)\end{array}$ & $\begin{array}{r}\text { Sig. } \\
(p)\end{array}$ \\
\hline Social media usage & $376-582$ & .871 & 13697.042 & 91 & 27.052 & .000 \\
\hline $\begin{array}{l}\text { SAPS-Smartphone addiction } \\
\text { (Overall) }\end{array}$ & $790-836$ & .738 & 9347.658 & 6 & 64.977 & .000 \\
\hline $\begin{array}{l}\text { SAPS-Disturbances of Adaptive } \\
\text { Functions }\end{array}$ & $360-789$ & .701 & 5872.654 & 10 & 45.097 & .000 \\
\hline SAPS-Virtual Life Orientation & $841-841$ & .500 & 1216.576 & 1 & 70.768 & .000 \\
\hline SAPS-Withdrawal & $420-821$ & .672 & 3699.912 & 6 & 48.619 & .000 \\
\hline SAPS-Tolerance & $361-813$ & .682 & 3592.008 & 6 & 48.349 & .000 \\
\hline $\begin{array}{l}\text { CAAS-Career Adaptability } \\
\text { (Overall) }\end{array}$ & $880-886$ & .829 & 15482.962 & 15 & 76.977 & .000 \\
\hline CAAS-Concern & $653-782$ & .835 & 12618.387 & 6 & 53.748 & .000 \\
\hline CAAS-Control & $415-608$ & .855 & 12517.521 & 15 & 54.562 & .000 \\
\hline CAAS-Curiosity & $640-787$ & .839 & 9917.682 & 15 & 49.966 & .000 \\
\hline CAAS-Confidence & $717-813$ & .868 & 15466.808 & 15 & 59.120 & .000 \\
\hline CFR-I-Career Futures (Overall) & $445-895$ & .763 & 13991.962 & 10 & 57.848 & .000 \\
\hline CFI-R-Career agency & $661-726$ & .937 & 21070.427 & 45 & 47.256 & .000 \\
\hline CFI-R-Occupational awareness & $661-692$ & .778 & 4463.882 & 10 & 45.186 & .000 \\
\hline CFI-R-Support & $746-780$ & 690 & 3106.830 & 6 & 59.752 & .000 \\
\hline CFI-R-Work-life balance & $677-748$ & .745 & 4002.525 & 6 & 52.544 & .000 \\
\hline CFI-R-Negative career outlook & $719-744$ & .751 & 4208,777 & 6 & 53.380 & .000 \\
\hline
\end{tabular}

\subsection{Tests of Hypotheses}

The hypothesized relationships were tested using correlations, simply and multiple linear regression analyses. The theoretical assumptions underlying regression analysis were met. The means, standard deviations, and inter-correlations for the variables of the study are as presented in Table 3.

First, the correlations revealed that smartphone addiction subdomains (disturbances of adaptive functions, virtual life orientation, withdrawal, and tolerance) were significantly and negatively related to all components of career adaptability (concern, control, curiosity and confidence) and four components of career futures (career agency, occupational awareness, work-life balance and negative career outlook) as expected. Virtual life orientation and withdrawal (variables of SAPS) did not demonstrate a significant relationship with support (variable of CFI-R). On the other hand, social media usage was positively related to subdomains of smartphone addiction, career adapt-abilities and career futures. Also, all components of career adaptability were positively related to all components of career futures. 
Table 3: Means, Standard Deviations, and Inter-Correlations for Variables $(\mathrm{N}=6259)$

\begin{tabular}{|c|c|c|c|c|c|c|c|c|c|c|c|c|c|c|c|c|c|c|c|}
\hline Variable & Mean & $\begin{array}{l}\text { Std. } \\
\text { Dev. }\end{array}$ & 1 & 2 & 3 & 4 & 5 & 6 & 7 & 8 & 9 & 10 & 11 & 12 & 13 & 14 & 15 & 16 & 17 \\
\hline $\begin{array}{l}\text { 1-Soc. media } \\
\text { usage }\end{array}$ & $\begin{array}{r}2.965 \\
0 \\
\end{array}$ & $\begin{array}{r}.6498 \\
7 \\
\end{array}$ & 1 & & & & & & & & & & & & & & & & \\
\hline $\begin{array}{l}\text { 2- } \\
\text { Smartphon } \\
\mathrm{e}\end{array}$ & $\begin{array}{r}2.349 \\
7\end{array}$ & $\begin{array}{r}.7303 \\
4\end{array}$ & $.322^{*}$ & 1 & & & & & & & & & & & & & & & \\
\hline $\begin{array}{l}\text { 3-Dist. of } \\
\text { Adap. } \\
\text { Funct. }\end{array}$ & $\begin{array}{r}2.393 \\
6\end{array}$ & $\begin{array}{r}.8724 \\
3\end{array}$ & $.227^{*}$ & $.837_{*}^{*}$ & 1 & & & & & & & & & & & & & & \\
\hline $\begin{array}{l}\text { 4-Virt. Life } \\
\text { Orientation }\end{array}$ & $\begin{array}{r}1.996 \\
1 \\
\end{array}$ & $\begin{array}{r}1.017 \\
4 \\
\end{array}$ & $.306_{*}^{*}$ & $.731_{*}^{*}$ & $.461_{*}^{*}$ & 1 & & & & & & & & & & & & & \\
\hline $\begin{array}{l}5- \\
\text { Withdrawal }\end{array}$ & $\begin{array}{r}2.416 \\
2 \\
\end{array}$ & $\begin{array}{r}.8981 \\
6 \\
\end{array}$ & $.292^{*}$ & $.787_{*}^{*}$ & $.433_{*}^{*}$ & $.623^{*}$ & 1 & & & & & & & & & & & & \\
\hline 6-Tolerance & $\begin{array}{r}2.405 \\
3 \\
\end{array}$ & $\begin{array}{r}.8805 \\
7 \\
\end{array}$ & $.244_{*}^{*}$ & $\begin{array}{r}.849^{*} \\
*\end{array}$ & $\begin{array}{r}.657^{*} \\
*\end{array}$ & $.491^{*}$ & $.533_{*}^{*}$ & 1 & & & & & & & & & & & \\
\hline $\begin{array}{l}\text { 7-Career } \\
\text { Adaptabilit } \\
\text { y }\end{array}$ & $\begin{array}{r}3.847 \\
8\end{array}$ & $\begin{array}{r}.7011 \\
5\end{array}$ & $.168_{*}^{*}$ & $\begin{array}{r}- \\
.216^{*} \\
*\end{array}$ & $\begin{array}{r}- \\
.184^{*} \\
*\end{array}$ & $\begin{array}{r}- \\
.146^{*} \\
*\end{array}$ & $\begin{array}{r}- \\
.149^{*} \\
* \\
\end{array}$ & $\begin{array}{r}- \\
.209^{*} \\
*\end{array}$ & 1 & & & & & & & & & & \\
\hline 8-Concern & $\begin{array}{r}3.860 \\
7\end{array}$ & $\begin{array}{r}.7986 \\
4\end{array}$ & $.138^{*}$ & $\begin{array}{r}- \\
.195^{*} \\
*\end{array}$ & $\begin{array}{r}- \\
.160^{*} \\
*\end{array}$ & $.136^{*}$ & $\begin{array}{r}- \\
.138_{*}^{*} \\
*\end{array}$ & $\begin{array}{r}- \\
.190^{*} \\
*\end{array}$ & $.883^{*}$ & 1 & & & & & & & & & \\
\hline 9-Control & $\begin{array}{r}3.914 \\
1\end{array}$ & $\begin{array}{r}.8016 \\
6\end{array}$ & $.162_{*}^{*}$ & $\begin{array}{r}- \\
.189^{*} \\
*\end{array}$ & $\begin{array}{r}- \\
.167^{*} \\
*\end{array}$ & $\begin{array}{r}- \\
.122^{*} \\
*\end{array}$ & $.121_{*}^{-}$ & $\begin{array}{r}- \\
.189^{*} \\
*\end{array}$ & $.880_{*}^{*}$ & $.709^{*}$ & 1 & & & & & & & & \\
\hline 10-Curiosity & $\begin{array}{r}3.650 \\
8\end{array}$ & $\begin{array}{r}.7760 \\
6\end{array}$ & $.152^{*}$ & $\begin{array}{r}- \\
.165^{*} \\
*\end{array}$ & $\begin{array}{r}- \\
.139^{*} \\
*\end{array}$ & $\begin{array}{r}- \\
.107^{*} \\
*\end{array}$ & $\begin{array}{r}- \\
.124^{*} \\
*\end{array}$ & $\begin{array}{r}- \\
.153^{*} \\
*\end{array}$ & $.859^{*}$ & $.707_{*}^{*}$ & $.635_{*}^{*}$ & 1 & & & & & & & \\
\hline $\begin{array}{l}\text { 11- } \\
\text { Confidence }\end{array}$ & $\begin{array}{r}3.965 \\
8\end{array}$ & $\begin{array}{r}.8194 \\
1\end{array}$ & $\begin{array}{r}.139^{*} \\
*\end{array}$ & $\begin{array}{r}- \\
.209^{*} \\
*\end{array}$ & $\begin{array}{r}- \\
.179^{*} \\
*\end{array}$ & $\begin{array}{r}- \\
.148^{*} \\
*\end{array}$ & $\begin{array}{r}- \\
.140^{*} \\
*\end{array}$ & $\begin{array}{r}- \\
.199^{*} \\
*\end{array}$ & $.888^{*}$ & $\begin{array}{r}.684^{*} \\
*\end{array}$ & $\begin{array}{r}.742^{*} \\
*\end{array}$ & $.681_{*}^{*}$ & 1 & & & & & & \\
\hline $\begin{array}{c}\text { 12-Career } \\
\text { Futures }\end{array}$ & $\begin{array}{r}3.425 \\
5\end{array}$ & $\begin{array}{r}.5465 \\
9\end{array}$ & $.247^{*}$ & $\begin{array}{r}- \\
.072^{*} \\
*\end{array}$ & $\begin{array}{r}- \\
.056^{*} \\
*\end{array}$ & $\begin{array}{r}- \\
.034^{*} \\
*\end{array}$ & $\begin{array}{r}- \\
.040^{*} \\
*\end{array}$ & $\begin{array}{r}- \\
.095^{*} \\
*\end{array}$ & $\begin{array}{r}.676^{*} \\
*\end{array}$ & $.604^{*}$ & $.590^{*}$ & $.583^{*}$ & $.597^{*}$ & 1 & & & & & \\
\hline $\begin{array}{l}\text { 13-Career } \\
\text { agency }\end{array}$ & $\begin{array}{r}3.700 \\
9\end{array}$ & $\begin{array}{r}.7343 \\
4\end{array}$ & $.173^{*}$ & $.175^{-}$ & $\begin{array}{r}- \\
.143^{*} \\
*\end{array}$ & $.112^{*}$ & $\begin{array}{r}- \\
.115^{*} \\
*\end{array}$ & $\begin{array}{r}- \\
.187^{*} \\
*\end{array}$ & $.731_{*}^{*}$ & $.644^{*}$ & $.655_{*}^{*}$ & $.613^{*}$ & $.655_{*}^{*}$ & $.895_{*}^{*}$ & 1 & & & & \\
\hline $\begin{array}{l}\text { 14-Occup. } \\
\text { Awareness }\end{array}$ & $\begin{array}{r}3.321 \\
9\end{array}$ & $\begin{array}{r}.7696 \\
8\end{array}$ & $.217_{*}^{*}$ & $\begin{array}{r}- \\
.058^{*} \\
*\end{array}$ & $\begin{array}{r}- \\
.054^{*} \\
*\end{array}$ & -.003 & -.023 & $\begin{array}{r}- \\
.090^{*} \\
*\end{array}$ & $.496_{*}^{*}$ & $\begin{array}{r}.435^{*} \\
*\end{array}$ & $.423^{*}$ & $\begin{array}{r}.469^{*} \\
*\end{array}$ & $\begin{array}{r}.416^{*} \\
*\end{array}$ & $\begin{array}{r}.792^{*} \\
*\end{array}$ & $\begin{array}{r}.658^{*} \\
*\end{array}$ & 1 & & & \\
\hline 15-Support & $\begin{array}{r}3.669 \\
3\end{array}$ & $\begin{array}{r}.7835 \\
5\end{array}$ & $.185_{*}^{*}$ & $\begin{array}{r}- \\
.090^{*} \\
*\end{array}$ & $.064_{*}^{-}$ & $.083^{-}$ & $\begin{array}{r}- \\
.073^{*} \\
*\end{array}$ & $\begin{array}{r}- \\
.079^{*} \\
*\end{array}$ & $.554_{*}^{*}$ & $.503^{*}$ & $.486_{*}^{*}$ & $.453_{*}^{*}$ & $.503^{*}$ & $.764_{*}^{*}$ & $.661_{*}^{*}$ & $\begin{array}{r}.469^{*} \\
*\end{array}$ & 1 & & \\
\hline $\begin{array}{l}\text { 16-Work-life } \\
\text { balance }\end{array}$ & $\begin{array}{r}3.632 \\
1\end{array}$ & $\begin{array}{r}.7794 \\
0\end{array}$ & $.175_{*}^{*}$ & $.154^{*}$ & $\begin{array}{r}- \\
.119^{*} \\
*\end{array}$ & $.104^{*}$ & $\begin{array}{r}- \\
.107^{*} \\
*\end{array}$ & $\begin{array}{r}- \\
.163^{*} \\
*\end{array}$ & $.625^{*}$ & $\begin{array}{r}.550^{*} \\
*\end{array}$ & $\begin{array}{r}.556^{*} \\
*\end{array}$ & $\begin{array}{r}.518^{*} \\
*\end{array}$ & $\begin{array}{r}.570^{*} \\
*\end{array}$ & $\begin{array}{r}.812^{*} \\
*\end{array}$ & $\begin{array}{r}.776^{*} \\
*\end{array}$ & $\begin{array}{r}.560^{*} \\
*\end{array}$ & $.613^{*}$ & 1 & \\
\hline $\begin{array}{c}\text { 17-Neg. Car. } \\
\text { Outlook }\end{array}$ & $\begin{array}{r}2.528 \\
9\end{array}$ & $\begin{array}{r}.9071 \\
5\end{array}$ & $.130_{*}^{*}$ & $.287_{*}^{*}$ & $.237^{*}$ & $.218^{*}$ & $.217_{*}^{*}$ & $.251_{*}^{*}$ & $\begin{array}{r}- \\
.179^{*} \\
*\end{array}$ & $\begin{array}{r}- \\
.137^{*} \\
*\end{array}$ & $.184^{*}$ & $\begin{array}{r}- \\
.125^{*} \\
*\end{array}$ & $\begin{array}{r}- \\
.179^{*} \\
*\end{array}$ & $.152^{*}$ & $\begin{array}{r}- \\
.188_{*}^{*}\end{array}$ & $.066_{*}^{*}$ & $.041_{*}^{-}$ & $.133^{*}$ & 1 \\
\hline
\end{tabular}

To test the hypotheses, regression analyses were carried out in four section. Firstly, a multiple regression analysis was carried out to test whether there is an impact on social media usage and components of smartphone addiction on career adaptability. The results revealed that social media usage has significantly and positively impact on career adaptability $(\beta=.265, p<$ .01 ), although components of smartphone addiction (disturbances of adaptive functions, virtual life orientation, withdrawal, and tolerance) has significantly and negatively impact on career adaptability $(\beta=-.085, \mathrm{p}<.01 ; \beta=-.077, \mathrm{p}<.01 ; \beta=-.064, \mathrm{p}<.01$, and $\beta=-.146, \mathrm{p}<.01$, respectively). The coefficient determination $\left(\Delta \mathrm{R}^{2}=.111\right)$ for career adaptability was acceptable 
level and indicated that $11.1 \%$ of the variation in the degree of career adaptability was explained and significantly influenced by social media usage $(+)$ and components of smartphone addiction (-). Also, Durbin-Watson value (1.665) described that as a lack of autocorrelation. Thus; H1, $\mathrm{H} 2 \mathrm{a}, \mathrm{H} 2 \mathrm{~b}, \mathrm{H} 2 \mathrm{c}$, and $\mathrm{H} 2 \mathrm{~d}$ were accepted. The results of the first multiple linear regression analysis of overall and sub-variables as dependent variables are shown in Table 4.

Table 4: First Multiple Linear Regression Analysis Results

\begin{tabular}{|c|c|c|c|c|c|c|c|c|}
\hline Variable & $\begin{array}{c}\text { Hyp. } \\
\text { Nu. }\end{array}$ & B & SE & $\beta$ & $\mathrm{t}$ & $\mathrm{p}$ & \multicolumn{2}{|c|}{ Collinearity Statistics } \\
\hline 1 (Constant) & & 3.669 & .043 & & 85.726 & .000 & Tolerance & VIF \\
\hline Social Media Usage & $\mathrm{H} 1$ & .286 & .014 & .265 & 20.914 & .000 & .883 & 1.137 \\
\hline $\begin{array}{l}\text { SA-Disturbances of } \\
\text { Adaptive Functions }\end{array}$ & $\mathrm{H} 2 \mathrm{a}$ & -.069 & .013 & -.085 & -5.266 & .000 & .543 & 1.842 \\
\hline SA-Virtual Life Orientation & $\mathrm{H} 2 \mathrm{~b}$ & -.053 & .011 & -.077 & -4.765 & .000 & .560 & 1.785 \\
\hline SA-Withdrawal & $\mathrm{H} 2 \mathrm{c}$ & -.050 & .013 & -.064 & -3.938 & .000 & .544 & 1.838 \\
\hline SA-Tolerance & $\mathrm{H} 2 \mathrm{~d}$ & -.116 & .014 & -.146 & -8.527 & .000 & .487 & 2.054 \\
\hline
\end{tabular}

$\mathrm{R}=.334, \Delta \mathrm{R}^{2}=.111, \mathrm{~F}=156.798$, Durbin-Watson $=1.665$

$\mathrm{SA}=$ Smartphone Addiction

Dependent variable=Career adaptability (Overall)

In the second section of the research, in the first simply linear regression analysis, social media usage regressed on the overall and components of career future. The results showed that social media usage as control variable contributes positively and significantly but in a low levels to the prediction of components of career futures-overall and its components; career agency, occupational awareness, support, work-life balance and negative career outlook $\left(\Delta \mathrm{R}^{2}=.06\right.$, $\mathrm{p}<.01 ; \Delta \mathrm{R}^{2}=.03, \mathrm{p}<.01 ; \Delta \mathrm{R}^{2}=.05, \mathrm{p}<.01 ; \Delta \mathrm{R}^{2}=.03, \mathrm{p}<.01 ; \Delta \mathrm{R}^{2}=.02, \mathrm{p}<.01$, respectively). Thus; H3, H3a, H3b, H3c, H3d and H3e were accepted. The results of the linear regression analysis of sub-variables of career futures as dependent variables are shown in Table 5.

Table 5: First Simply Linear Regression Analysis Results

\begin{tabular}{|l|c|c|c|c|c|r|r|r|}
\hline Dependent Variables & $\begin{array}{c}\mathrm{Hyp} . \\
\mathrm{Nu} .\end{array}$ & $\mathrm{B}$ & $\mathrm{SE}$ & $\beta$ & $\mathrm{F}$ & $\begin{array}{c}(\mathrm{Adj} .) \\
\Delta \mathrm{R}^{2}\end{array}$ & $\mathrm{t}$ & $\mathrm{p}$ \\
\hline $\mathrm{CF}$ (Overall) & $\mathrm{H} 3$ & .207 & .010 & .247 & 113.790 & .061 & 20.137 & .000 \\
\hline CF-Career agency & $\mathrm{H} 3 \mathrm{a}$ & .195 & .014 & .173 & 100.548 & .030 & 13.862 & .000 \\
\hline $\begin{array}{l}\text { CF-Occupational } \\
\text { awareness }\end{array}$ & $\mathrm{H} 3 \mathrm{~b}$ & .257 & .015 & .217 & 308.444 & .047 & 17.563 & .000 \\
\hline CF-Support & $\mathrm{H} 3 \mathrm{c}$ & .223 & .015 & .185 & 221.198 & .034 & 14.873 & .000 \\
\hline CF-Work-life balance & $\mathrm{H} 3 \mathrm{~d}$ & .210 & .015 & .175 & 197.788 & .030 & 14.064 & .000 \\
\hline $\begin{array}{l}\text { CF-Negative career } \\
\text { outlook }\end{array}$ & $\mathrm{H} 3 \mathrm{e}$ & .182 & .017 & .130 & 108.342 & .017 & 10.409 & .000 \\
\hline
\end{tabular}

Independent variable $=$ Social media usage

$\mathrm{CF}=$ Career Future; Hyp. Nu=Hypothesis Number and its components of smartphone addiction 
In the third section of the research, in the second multiple linear regression analysis where career futures (overall) was predicted by career adaptability and smartphone addiction with their components (except tolerance) as control variables. These control variables positively and significantly contributed to the prediction of career futures $\left(\Delta R^{2}=.464, p<.01\right)$. Subdomains of smartphone addiction; disturbance of adaptive functions $(\beta=.055, p<.01)$, virtual life orientation $(\beta=.034, p<.01)$, and withdrawal $(\beta=.027, p<.01)$ positively and significantly related to career futures. Also, components of career adaptability; concern $(\beta=.220, p<.01)$, control $(\beta=.180, \mathrm{p}<.01)$, cruosity $(\beta=.190, \mathrm{p}<.01)$, and confidence $(\beta=.198 \mathrm{p}<.01)$ positively and significantly related to career futures. However, tolerance was found to be non-significant ( $\beta=-.019, p>.05)$. Thus; H4a, H4b, H4c, H5a, H5b, H5c, and H5d were accepted while H4d was rejected. The results of the second multiple linear regression analysis of components as dependent variables are shown in Table 6.

Table 6: Second Multiple Linear Regression Analysis Results

\begin{tabular}{|l|c|r|c|c|r|r|r|r|}
\hline Variable & $\begin{array}{c}\text { Hyp. } \\
\text { Nu. }\end{array}$ & \multicolumn{1}{c|}{$\mathrm{B}$} & \multicolumn{1}{c|}{$\mathrm{SE}$} & \multicolumn{1}{c|}{$\beta$} & \multicolumn{1}{c|}{$\mathrm{t}$} & \multicolumn{1}{c|}{$\mathrm{p}$} & \multicolumn{2}{|c|}{ Collinearity Statistics } \\
\hline 1 (Constant) & & 1.218 & .036 & & 33.379 & .000 & Tolerance & \multicolumn{1}{c|}{ VIF } \\
\hline $\begin{array}{l}\text { SA-Disturbances of } \\
\text { Adaptive Functions }\end{array}$ & $\mathrm{H} 4 \mathrm{a}$ & .035 & .008 & .055 & 4.405 & .000 & .541 & 1.848 \\
\hline $\begin{array}{l}\text { SA-Virtual Life } \\
\text { Orientation }\end{array}$ & $\mathrm{H} 4 \mathrm{~b}$ & .007 & .007 & .034 & 2.778 & .005 & .559 & 1.789 \\
\hline SA-Withdrawal & $\mathrm{H} 4 \mathrm{c}$ & .004 & .008 & .027 & 2.177 & .002 & .543 & 1.842 \\
\hline SA-Tolerance & $\mathrm{H} 4 \mathrm{~d}$ & -.012 & .008 & -.019 & -1.398 & .162 & .482 & 2.076 \\
\hline CA-Concern & $\mathrm{H} 5 \mathrm{a}$ & .151 & .010 & .220 & 14.515 & .000 & .373 & 2.679 \\
\hline CA-Control & $\mathrm{H} 5 \mathrm{~b}$ & .123 & .010 & .180 & 11.793 & .000 & .369 & 2.709 \\
\hline CA-Cruosity & $\mathrm{H} 5 \mathrm{c}$ & .134 & .010 & .190 & 13.352 & .000 & .422 & 2.367 \\
\hline CA-Confidence & $\mathrm{H} 5 \mathrm{~d}$ & .132 & .010 & .198 & 12.869 & .000 & .361 & 2.769 \\
\hline
\end{tabular}

$\mathrm{R}=.681, \Delta \mathrm{R}^{2}=.464, \mathrm{~F}=677.181$, Durbin-Watson=1.741, Hyp. Nu=Hypothesis Number

$\mathrm{SA}=$ Smartphone Addiction, $\mathrm{CA}=$ Career Adaptability

Dependent variable $=$ Career futures $($ Overall)

In the fourth section, second simply linear regression analysis, smartphone addiction as control variables contributed negatively and significantly $(\beta=-.216, p<.01)$ but in a low level to the prediction of career adaptability $\left(\Delta \mathrm{R}^{2}=.047, \mathrm{p}<.01\right)$. Thus, the hypothesis that "smartphone addiction has a negative impact on career adaptability" (H2) was accepted. The results of the linear regression analysis are shown in Table 7.

Table 7: Second Simply Linear Regression Analysis Results

\begin{tabular}{|l|c|c|c|c|c|c|}
\hline Variable & $\begin{array}{c}\text { Hyp. } \\
\text { Nu. }\end{array}$ & $\mathrm{B}$ & $\mathrm{SE}$ & $\beta$ & $\mathrm{t}$ & $\mathrm{p}$ \\
\hline 1 (Constant) & & 4.335 & .029 & & 148.723 & .000 \\
\hline Smartphone Addiction (Overall) & $\mathrm{H} 2$ & -.207 & .012 & -.216 & 20.137 & .000 \\
\hline
\end{tabular}
$\begin{aligned} & \mathrm{R}=.216, \Delta \mathrm{R}^{2}=.047, \mathrm{~F}=306.685, \text { Hyp. Nu=Hypothesis Number } \\
& \text { Dependent variable=Career Adaptability (Overall) }\end{aligned}$


In the third multiple linear regression analysis, smartphone addiction (overall) and career adaptability (overall) as control variables contributed positively and significantly to the prediction of career futures $\left(\Delta \mathrm{R}^{2}=.463, \mathrm{p}<.01\right)$. Smartphone addiction (overall) $(\beta=.077, \mathrm{p}<$ $.01)$ and career adaptability (overall) $(\beta=.693, \mathrm{p}<.01)$ positively and significantly related to career futures. Thus, the hypothesis that "smartphone addiction has a negative impact on career career futures" (H4) and "career adaptability has a negative impact on career futures" (H5) were accepted. The results of the multiple linear regression analysis of components as dependent variables are shown in Table 8.

Table 8: Third Multiple Linear Regression Analysis Results

\begin{tabular}{|l|r|c|c|c|r|r|r|c|}
\hline Variable & $\begin{array}{c}\text { Hyp. } \\
\text { Nu. }\end{array}$ & \multicolumn{1}{c|}{$\mathrm{B}$} & $\mathrm{SE}$ & \multicolumn{1}{c|}{$\beta$} & \multicolumn{1}{c|}{$\mathrm{t}$} & $\mathrm{p}$ & \multicolumn{2}{|c|}{ Collinearity Statistics } \\
\hline 1 (Constant) & & 1.211 & .036 & & 33.321 & .000 & Tolerance & VIF \\
\hline $\begin{array}{l}\text { Smartphone Addiction } \\
\text { (Overall) }\end{array}$ & $\mathrm{H} 4$ & .058 & .007 & .077 & 8.142 & .000 & .541 & 1.848 \\
\hline $\begin{array}{l}\text { Career Adaptability } \\
\text { (Overall) }\end{array}$ & $\mathrm{H} 5$ & .540 & .007 & .693 & 72.996 & .000 & .559 & 1.789 \\
\hline
\end{tabular}

$\mathrm{R}=.680, \Delta \mathrm{R}^{2}=.463, \mathrm{~F}=2694.767$, Durbin-Watson=1.741, Hyp. Nu=Hypothesis Number

Dependent variable $=$ Career futures $($ Overall $)$

\section{DISCUSSION}

Researcher examined the effects of social media usage on career adaptability and overall career futures and its components (career agency, occupational awareness, support, work-life balance, and negative career outlook). The results indicated that the effects of social media usage on career adaptability (H1), overall career futures (H3), career agency (H3a), occupational awareness $(\mathrm{H} 3 \mathrm{~b})$, support $(\mathrm{H} 3 \mathrm{c})$, work-life balance $(\mathrm{H} 3 \mathrm{~d})$, and negative career outlook (H3e) were supported. Regarding social media usage (H1), result of this research is consistent with those of Kettunen et al. (2015). Kettunen et al. (2015) suggested that effective usage and competency for social media conceived as an ability to utilise social media for collaborative career exploration and cocareering. Nevertheless, the results of this study are consistent with the views of Kettunen et al. (2015) that effective usage and competency for social media allows to gather information about career opportunities and career adaptability. Adolescents who possess high levels of ability to use social media enhanced motivation to job seeking, prepare themselves for good positions and build the career futures.

As expected, the results supported hypothesizes that overall smartphone addiction $(\mathrm{H} 2)$, disturbances of adaptive functions (H2a), virtual life orientation $(\mathrm{H} 2 \mathrm{~b})$, withdrawal $(\mathrm{H} 2 \mathrm{c})$, and tolerance $(\mathrm{H} 2 \mathrm{~d})$ negatively affects the career adaptability. The results indicated that the effects of overall smartphone addiction (H4), disturbances of adaptive functions (H4a), virtual life 
orientation (H4b), withdrawal (H4c), overall career adaptation (H5), concern (H5a), control $(\mathrm{H} 5 \mathrm{~b})$, cruosity $(\mathrm{H} 5 \mathrm{c})$, and confidence $(\mathrm{H} 5 \mathrm{~d})$ on career futures were supported. However, tolerance didn't have significant impacts on career futures $(\mathrm{H} 4 \mathrm{~d})$. These results are close but not exact consistent with those of previous studies. Vaghefi et al. (2017) revealed that overuse of smartphone to be considered addictive have negatively effects on the productivity and performance of users and increase the job turnover for professionals. Also, Lorenz (2015) determined that smartphone addiction is the biggest productivity killers in the workplace. Thus, this research concluded that overall smartphone addiction and its sub-domains, except tolerance, negatively and directly affect career adaptability and career futures. There isn't significant impact of tolerance on career futures.

The implication of this results is that perception of career adaptability and career futures among high school students/adolescents in Turkey, can be conveniently improved through efficiently using social media, while reducing smartphone usage. Early studies reported that social media has given impetus to building and exploiting connections for career in all its aspect by providing information on employability and updating skill set (Benson et al., 2014), cocareering (Kettunen et al., 2015), kinship, friendship (Küçükali, 2016), personal goal orientation, perceived social support, career self-efficacy sources (Ebenehi et al., 2016), and career advancement (McCabe, 2017). This study also concluded that the career adaptability skill among adolescents can be enhanced by involving them in making self-decisions, taking responsibility for their actions, preparing for the future, and goal setting activities. Adolescents also should be supported by motivating them becoming curious about new opportunities, helping them to observing different ways of doing things, learning new skills, overcoming obstacles, and solving their problems.

As emphasized above, career futures perception among adolescents can be enhanced via social media by heightening awareness. Opportunities should be given to adolescent to gain awareness of their strengths and priorities in their life, to keep current with changes job market, occupational, industrial and economic trends, and to realize and operate work-life balance by sharing information through social media. The significant of perceived support from family, friends, and others in their life can not be ignored in the process of preparing the career futures of the adolescents, however, this support should not adversely affect the self-confidence of adolescents. Another important factor is that adolescents get rid of negative outlook about their careers (Rottinghaus et al., 2017). 
Another implication of this results to the high school managements and close circle of adolescents in Turkey is that teachers and families have responsibilities to prevent students/adolescents from excessive using the smartphone to avoid being addicted. Smartphone addiction negatively impacts career adaptability due to reduced academic performance (Samaha \& Hawi, 2016). Teachers and managers of high school, especially parents have to control their smartphone usage time and whether the adolescents are doing homework. Parents should not buy internet for adolescents to use with smartphone. Parents and high school management also should motivate them to build their careers. This can be done by looking for opportunities to grow as a person, doing what's right for him/her, planning how to achieve his/her goals, and performing tasks efficiently (Savickas and Porfeli, 2012).

In addition, the high school students, living in adolescense, need to establish plans for their career adaptability and career futures. However, smartphone addiction prevents its smartphone users from working for career adaptability and career futures. A study concluded that overuse of smartphone with regard IT addiction have negatively effect on the productivity and performance of users (Vaghefi et al., 2017) and these are the building blocks of creating a career future. Nonetheless, the adolescents can improve their career futures through overcoming potential barriers that may exist in career, having support from their families, teachers, and others. An additional contribution of this research is that impact of social media usage and smartphone addiction on career adaptability and career futures were tested in Turkey, which is the first use of these scales to measure all of these variables are together in a non-Western context, as far as the researcher's know. As a result of the factor analyses of scales were found to be consistent with the South Korean (Kim et al., 2014) and Western context (Savickas and Porfeli, 2012; Rottinghaus et al., 2012). Therefore, these analyses revealed that the translated scales perform were satisfaction and that they can be successfully used in a non-Western context generally or at least only in Turkey. The results of the this study should be taken into consideration in light of two limitations. The first limitation is partial participation (67\%). Another mean, not all students in all the program of studies in the high schools were used, thus, the result of this study should be cautious to generalize. So the researchers should conduct to cover other high school in Turkey in future. Second, future researchers should try to analysis with structural equation modeling (SEM) for defining causal relationship between the predictors and the outcome variables for more plausible results. 


\section{CONCLUSION}

The aim of this study was to examine the impact of social media usage and smartphone addiction on career adaptability and career futures. Researcher established a path model to analyze these four factors. Our results showed that social media usage positively predicted overall career adaptability and career futures and their components. Also overall smartphone addiction and its components (disturbances of adaptive functions, virtual life orientation, and withdrawal) except tolerance, positively predicted overall career futures and its components, whereas overall career adaptability and its components negatively predicted smartphone addiction. Although no significant relationship was observed between tolerance which is one of the components of smartphone addiction and career futures, the majority of the study hypotheses were supported. Overall, these results provide a knowledge base regarding the benefit of the social media usage and negative effects of smartphone addiction and increase information for the improving of career adaptability and career futures. 


\section{REFERENCES}

Aljomaa, S.S., Al.Qudah, M.F., Albursan, I.S., Bakhiet, S.F., and Abduljabbar, A.S. (2016). Full length article: "Smartphone addiction among university students in the light of some variables", Computers in Human Behaviour, 61, 155-164. doi:10.1016/j.chb.2016.03.041

Anders, G. (2012). "Smart social media helps jobs find you", HBR. retrieved August 09, 2017, available at:. https://hbr.org/2012/03/smart-social-media-helps-jobs.

Bandura, A. (1997). Self-efficacy: The exercise of control. New York: Freeman

Benson, V., Morgan, S., and Filippaios, F. (2014). "Social career management: Social media and employability skills gap", Computers in Human Behaviour, 30, 519-525.

Brunborg, G.S., Andreas, J.B., and Kvaavik, E. (2017). "Social media use and episodic heavy drinking among adolescents", Psychological Reports, 120(3), 475-490.

Cash, H., Rae, C.D., Steel, A.H., and Winkler, A. (2012). "Internet addiction: A brief summary of research and practice", Current Psychiatry Review, 8, 292-298.

Cha, S-S. and Seo, B-K. (2018). Smartphone use and smartphone addiction in middle school students in Korea: Prevalence, social networking service, and game use. Health Psychology Open, January-June, 1-15. DOI:10.1177/2055102918755

Chiu, S.-I. (2014). The relationship between life stress and smartphone addiction on taiwanese university student: A mediation model of learning self-efficacy and social self-Efficacy. Computers in Human Behaviour, 34, 49-57. http://dx.doi.org/10.1016/j.chb.2014.01.024

Creed, P.A., Patton, W., and Bartrum, D. (2002). "Multidimensional properties of the LOT-R: Effects of optimism and pessimism on career and well-being related variables in adolescents", Journal of Career Assessment, $10(1), 42-61$.

Dama, N. (2017). “Türkiye'nin eğitim, öğrenim ve çalışma sürecinde olmayan gençleri (The young not in education, employment and training in Turkey)", SETA, 198, 1-27.

Demirci, K., Orhan, H., Demirdas, A., Akpinar, A., and Sert, H. (2014). "Validity and reliability of the Turkish Version of the Smartphone Addiction Scale in a younger population", Bulletin of Clinical Psychopharmacology, 24(3), 226-234.

Ebenehi, A.S., Rashid, A.M. and Bakar, A.R. (2016). "Predictors of career adaptability skill among higher education students in Nigeria", International Journal for Research in Vocational Education and Training, 3(3), 212-229.

Eshelman, A.J. and Rottinghaus, P.J. (2015). "Viewing adolescents' career futures through the lenses of socioeconomic status and social class", The Career Development Quarterly, 63(4), 320-332.

Fernandes, R. and Bance, L.O. (2015). "Pathway from adolescent's career indecision to career decision: Basis for career guidance program", Indian Journal of Positive Psychology, 6(2), 136-142.

Field, A. (2009). Discovering statistics using SPSS. third edition. London: SAGE Publications.

Greenfield, D.N. (1999). "Virtual addiction: Sometimes new technology can create new problems", In Greenfield, D.N. (Ed.), Virtual Addiction (pp. 1-20). California, USA: New Harbinger Publications.

Ginevra, M.C., Pallini, S., Vecchio, G.M., Nota, L., and Soresi, S. (2016). "Future orientation and attitudes mediate career adaptability and decidedness", Journal of Vocational Behavior, 95-96, 102-110. DOI: 10.1016/j.jvb.2016.08.003.

Giunchiglia, F., Zeni, M., Gobbi, E., Bignotti, E., and Bison, I. (2018). "Mobile social media usage and academic performance", Computers in Human Behavior, 82, 177-185.

Hall, M. Farkas, G. (2011). “Adolescent cognitive skills, attitudinal/behavioral traits and career wages”, Social Forces, 89(4), 1261-1286.

Hartung, P.J. and Cadaret, M.C. (2017). "Career adaptability: Changing self and situation for satisfaction and success”, In Maree, K.(Ed.), Psychology of Career Adaptability, Employability and Resilience (pp. 1528). Springfield, MA, USA: Springer International Publishing. DOI 10.1007/978-3-319-66954-0_2. 
Hong, F. Y., Chiu, S. I., and Huang, D. H. (2012). "A model of the relationship between psychological characteristics, smartphone addiction and use of mobile phones by Taiwanese female university students", Computer in Human Behavior, 28(6), 2152-2159. http://dx.doi.org/10.1016/j.chb.2012.06.020.

Kanten, S. (2012). “Kariyer uyum yetenekleri ölçeği: Geçerlilik ve güvenilirlik çalışması (Eng: Career adaptabilities scale: A study of validity and reliability)", Journal of Süleyman Demirel University Institution of Social Sciences, 2(16), 191-205.

Kettunen, J., Sampson Jr., J.P., and Vuorinen, R. (2015). “Career practitioners' conceptions of competency for social media in career services", British Journal of Guidance and Counselling, 43(1), 43-56.

Küçükali, A. (2016). "Social media usage of college students: The case of Atatürk University", Bartın Univ. İ.İ.B.F. Dergisi, 7(13), 531-546.

Kim, D., Lee, Y., Lee, J., Nam, J.K., and Chung, Y. (2014). "Development of korean smartphone addiction proneness scale for youth", PLoS ONE, 9(5), e97920.

Kim, S.E., Kim, J.W., and Jee, Y.S. (2015). "Relationship between smartphone addiction and physical activity in Chinese international students in Korea", Journal of Behavioral Addictions, 4(3), 200-205.

Kononova, R. (2017). How Social Media Can Lead to Your Future Career. Retrieved from: https://career.du.edu/blog/2017/01/04/how-social-media-can-lead-to-your-future-career/ (10.07.2018)

Kwon M., Lee, J.Y., Won, W.Y., Park J.W., Min, J.A., and Hahn, C. (2013). "Development and validation of a smartphone addiction scale (SAS)". PLoS ONE, 8(2), e56936.

Lee, S., Lee, C., and Lee, C. (2016). "Smartphone addiction and application usage in Korean adolescents: Effects of mediation strategies”, Social Behavior and Personality: An İnternational Journal, 44, 1525-1534.

Lorenz, M. (2015). "New careerbuilder survey reveals "the most common and strangest productivity killers at work", CISION PRNewswire. Jun 11, 2015, retrieved 24.09.2017, available at: http://www.prnewswire.com/news-releases/new-careerbuilder-survey-reveals-the-most-common-andstrangest-productivity-killers-at-work-300097282.html.

Mccabe, M.B. (2017). "Social media marketing strategies for career advancement: An analysis of LinkedIn", International Journal of Business and Behavioral Sciences, 29(1), 85-99.

Mills, C. (2013). How social media can boost your professional profile. Retrieved from: https://www.theguardian.com/careers/social-media-boost-professional-profile (10.07.2018).

Moreno, M.A., D’Angelo, J., and Whitehill, J. (2016). "Social media and alcohol: Summary of research, intervention ideas and future study directions", Media and Communication, 4(3), 50-59.

Patton, W., Bartrum, D.A., and Creed, P.A. (2004). "Gender differences for optimism, self-esteem, expectations and goals in predicting career planning and exploration in adolescents", International Journal for Educational and Vocational Guidance, 4(2-3), 193-209.

Taber, B.J. and Blankemeyer, M. (2015). "Future work self and career adaptability in the prediction of proactive career behaviors", Journal of Vocational Behavior, 86, 20-27.

Roman, L.A. (2014). "Using social media to enhance career development opportunities for health promotion professionals", Health Promotion Practice, 15(4), 471-475.

Rottinghaus P., Day, S.X., and Borgen, F.H. (2005). "The career futures inventory-A measure of career-related adaptability and optimism”, Journal of Career Assessment, 13(1), 3-24.

Rottinghaus, P.J., Buelow, K.L., Matyja, A., and Schneider, M.R. (2012). “The career futures inventory-revised: Measuring dimensions of career adaptability”, Journal of Career Assessment, 20(2), 123-139.

Rottinghaus, P.J., Eshelman, A., Gore, J.S., Keller, K.J., Schneider, M., and Harris, K.L. (2017). "Measuring change in career counseling: Validation of the career futures inventory-revised", International Journal for Educational and Vocational Guidance, 17(1), 61-75.

Rutten, M., Ros, A., Kuijpers, M., and Kreijns, K. (2016). 'Usefulness of social network sites for adolescents' development of online career skills", Journal of Educational Technology and Society, 19(4), 140-150.

Salehan, M. and Negahban, A. (2013). "Social networking on smartphones: When mobile phones become addictive", Computers in Human Behaviour, 29(6), 2632-2639. 
Samaha, M. and Hawi, N.S. (2016). "Full length article: Relationships among smartphone addiction, stress, academic performance, and satisfaction with life", Computers in Human Behaviour, 57, 321-325

Schwarzer, R., and Jerusalem, M. (1995). "Optimistic self-beliefs as a resource factor in coping with stress", In S. E. Hobfoll and M. W. de Vries (Eds.), Extreme stress and communities: Impact and interventions (pp. 159-177). Dodrecht, NL: Kluwer Academic.

Savickas, M.L. (1997). “Adaptability: An integrative construct for life-span, life-space theory”, Career Development Quarterly, 45, 247-259.

Savickas, M.L. and Porfeli, E.J. (2012). "Career adapt-abilities scale: Construction, reliability, and measurement equivalence across 13 countries”, Journal of Vocational Behaviour, 80(3), 661-673.

Super, D.E. (1980). “A life-span, life-space approach to career development”, Journal of Vocational Behaviour, $16,282-298$.

Walsh, B. and Volini, E. (2017). Rewriting the rules for the digital age. 2017 Deloitte Global Human Capital Trends, Deloitte University Press. retrieved January 3, 2017, available at:.https://www2.deloitte.com/content/dam/Deloitte/us/Documents/human-capital/hc-2017 globalhuman-capital-trends-us.pdf

Vaghefi, I., Lapointe, L., and Boudreau-Pinsonneault, C. (2017). “A typology of user liability to IT addiction”, Information Systems. 27(2), 125-169.

Young, K. (1998). Caught in The Net: How to Recognize The Signs of Internet Addiction-And A Winning Strategy for Recovery, First Edition, New York: John Wiley and Sons. 